\title{
THE "OTHER" TREATY OF LAUSANNE: THE AMERICAN PUBLIC AND OFFICIAL DEBATE ON TURKISH-AMERICAN RELATIONS
}

\author{
JOHN M. VANDER LIPPE
}

On August 6, 1923 Joseph Grew, the American representative at the Lausanne Conference, and Ismet Pasha, the Foreign Minister of the nationalist government of Ankara, signed a Treaty of Amity and Commerce in Lausanne, Switzerland. The "other" Treaty of Lausanne was meant to establish diplomatic and commercial relations between the United States and the new Turkish Government. Replacing agreements between America and the Ottoman Empire, which were severed when the United States entered World War I in 1917, this new treaty also signified the United States' recognition of the independence and sovereignty of the new Turkish state.

In Turkey, the treaty with the United States was seen as an extension of the Lausanne Treaty, normalizing relations between the new Turkish Government and the European Powers. But in the United States, the treaty led to an official and public controversy which delayed its ratification, and resulted in its rejection in 1927 by the United States Senate. Still, the debate surrounding the treaty continued, lasting seven year from its signing in 1923 until 1930 when the Senate finally accepted another, yet virtually identical, treaty with the Turkish Republic.

In the United States, the treaty became one of the instrumental issues in a larger reevaluation of American foreign policy in the post-war era and America's place in global affairs. In this context, American official and public attitudes divided over American-Turkish relations reflecting decisively different views of the Ottoman Empire and the future of Turkey. Overall, this debate led to reevaluation of existing views regarding the Ottoman Empire, the Turks and the newly established Turkish Republic. But at the same time, the controversy reinforced images of the "exotic and terrible Turk," and 
transferred them from the Ottoman Empire to the new Turkish Republic in the minds of both policy-makers and the American public. The seven year delay in the ratification of the treaty served to sharpen these opposing views, and made them an integral aspect of American policy towards Turkey.

\section{American-Ottoman Relations and the "Terrible Turk":}

The United States and the Ottoman Empire first established diplomatic relations with the Treaty of May $10,1830 .{ }^{1}$ With the treaty, the Americans claimed the same rights and privileges in the Ottoman Empire accorded to European nations under the terms of the capitulations. ${ }^{2}$ The treaty also allowed American missionaries, who had been working in the Empire since 1820 , to establish more missions, schools and hospitals in the Empire. ${ }^{3}$ The 1830 treaty remained the basis of Ottoman-American relations until the First World War.

Despite suspicion that the missionaries were spreading anti-Ottoman propaganda among the Christians of the Empire, the Ottoman Government was bound by the capitulations to allow them to continue their activities, which increased throughout the nineteenth century. American missionaries, sponsored mostly by the Protestant Congregationalist and Presbyterian churches, operated under the control of the American Board of Commissioners for Foreign Missions. The original mission at İzmir was followed by others at İstanbul, Trabzon, Erzurum, Sivas, Diyarbakır, Adana, Gaziantep, Maraş, Urfa and Van. ${ }^{4}$ According to the Annual Report of the American Board of Commissioners for Foreign Missions, by 1914, 151

${ }^{1}$ For more detailed analysis of early relations between the United States and the Ottoman Empire, and the negotiations leading to the treaty, see Leland J. Gordon, American Relations with Turkey, 1830-1930: An Economic Interpretation, Philadelphia, 1932, pp. 7-12.

${ }^{2}$ Under the capitulations, American citizens and Ottoman subjects with American passports had personal immunity, as well as protection of property, against the jurisdiction of the Ottoman courts. The capitulations were first granted by Sultan Süleyman I to Venice, Genoa and France in the 16 th century, in order to encourage trade. They granted low tariffs on goods from these countries, and allowed foreign consuls to exercise power over their citizens separate from the Ottoman courts. Although originally reciprocal, by the 19th century the European Powers were able to use the capitulations to control the Ottoman economy and finances. See Stanford J. Shaw, History of the Ottoman Empire and Modern Turkey, Vol. I, Cambridge, 1976, pp. 97-98.

${ }^{3}$ Robert Daniel, American Philanthropy in the Near East, 18201960, Athens, Ohio, 1970, pp. 41-70.

${ }^{4}$ Albert H. Lybyer,"America's Missionary Record in Turkey," Current History, XIX (1924), 804. 
American missionaries, along with 1,204 Ottoman Christians, operated 137 churches, 9 hospitals, 8 colleges, 46 secondary schools and 369 elementary schools with an enrollment of 25,199 mostly Christian, and some Muslim students. 5

The American missionary operations were framed, not only in terms of spreading Christianity, but also ideas of "American progress and economic growth" within the Ottoman Empire. The establishment of Robert College in Istanbul exemplified this symbiosis of spiritual and material "advancement." 6 Along with missionaries and educators, merchants represented America's ideological and economic expansion in the Middle East in the nineteenth century, making the Ottoman Empire both a spiritual mission, and a market for American goods and a source for raw materials.

By 1914 American imports from the Ottoman Empire totalled more than \$20 million, while exports to the Empire reached about \$3 million. ${ }^{7}$ Besides interest in leather, figs and other basic commodities, the two largest American commercial interests were centered on tobacco and oil. ${ }^{8}$ Prominent brands such as Camel, Lucky Strike and Fatima cigarettes all claimed to contain Turkish tobacco for extra flavor. Several tobacco companies owned warehouses in Izmir and İstanbul, with investments adding up to several million dollars. In addition, American oil interests, such as the Standard Petroleum Company, imported oil from the United States and sought

5 American Board of Commissioners for Foreign Missions, The One Hundred and Eighth Annual Report, Boston, 1918, p. 170.

${ }^{6}$ The College was founded in Istanbul in 1863 by Cyrus Hamlin, a former missionary, with the financial support of a wealthy New Yorker, Christopher Robert. This was followed eight years later by the opening of Istanbul Girls' College. Daniel, American Philanthropy in the Near East, pp. 7192; Mary Mills Patrick, A Bosphorus Adventure, Stanford, 1934, pp. 28-46. Patrick was president of Istanbul Girls' College from 1890 to 1924 , when she retired.

${ }^{7}$ For example, in 1912, the United States imported $\$ 8.6$ million worth of tobacco, as well as $\$ 1.37$ million worth of fruits and nuts. Other major imports were rugs and carpets, raw wool, and drugs, dyes, and chemicals, which added up to more than $\$ 5$ million. In 1912 cottonseed and oleo oils made up the major American exports to Turkey. Other export products included processed cotton and wool, mineral oils, rubber, and agricultural and industrial machinery, totalling $\$ 3.3$ million. Gordon, American Relations with Turkey, pp. 60, 65-66.

${ }^{8}$ Gordon, American Relations with Turkey, pp. 49, 65; see also, Şevket Pamuk, Osmanlı Ekonomisi ve Dünya Kapitalizmi: 18201913 (The Ottoman Economy and World Capitalism, 1820-1913), Ankara, 1984. 
concessions for drilling rights in the Empire. ${ }^{9}$ Interest in mineral resources and facilitation of the transportation of goods by rail spurred American investors such as those represented by Admiral Colby Chester and his sons. The Chesters entered negotiations in 1909 with the Ottoman Government for the right to construct a railroad from Aleppo to Iskenderun and exploit mineral resources in eastern Anatolia. ${ }^{10}$

With the ircrease in trade and missionary activities, the Ottoman Empire began to enter the imagination of Americans as part of the "East," the "Orient," an exotic, mysterious place, full of intrigue. ${ }^{11}$ What distinguished the Ottoman Empire from the "Orient" of China and Japan was Islam. In the American imagination, Islam carried images of war, fostered in Christian teaching since the age of the Crusades. Furthermore, the popular conception of the Ottoman Empire included men is fezzes and long black moustaches carrying scimitars, and women in veils living in lavish harems. The stereotypical images were reinforced by advertising and marketing of commodities from the Empire, such as tobacco and rugs. Missionaries, businessmen and diplomats who spent time in the Ottoman Empire often reinforced this construction of the "foreign and strange" in their letters, public speeches and memoirs. ${ }^{12}$

${ }^{9}$ For analysis of the international aspects of oil politics and American involvement in oil drilling in the Ottoman Empire, see Daniel Yergin, The Prize, New York, 1991, pp. 184-206. An early account of American oil exports to the Ottoman Empire is in Samuel Cox, Diversions of a Diplomat in Turkey, New York, 1887, pp. 157-159.

10 While the Ottoman Government viewed the Chester proposal as a chance to reduce European interference, the European Powers opposed the increase in American influence implied by the concession. The Germans, claiming the Chester concession would infringe on the Berlin-Baghdad Railroad concession, were able to convince the Ottoman Government not to act on the concession. The Chester concession was not granted before the war began, but following the war, Admiral Chester proposed a new project that would include oil exploration. The post-war renewal on negotiations for the Chester concession, and the role of the State Department in supporting the claim, became an issue both in Turkish-American relations and in the debate within America over restoration of diplomatic relations. See John DeNovo, American Interests and Policies in the Middle East: 19001939, Minneapolis, 1963, pp. 58-87, 210-228.

${ }^{11}$ For some, the "East" also represented filth and disease. See F.L. Nichols, "Getting Acquainted with the Terrible Turk and Snubbing Gentle Cholera Asiatic," The Hospital Corps Quarterly, 5 (1/1921), 8-10.

${ }^{12}$ Edward Said, in his book Orientalism (New York, 1978), examines in detail this phenomenon of treating the East as different, and inferior to the West. It is imperative to note that the stereotypes in this imagery were meant to reinforce the concept of "Western superiority" and to justify Western intervention and economic expansionism. 
Along with this complex merging of exotic "Oriental," "Islamic" and "Ottoman" images, a darker and threatening concept of the "Terrible Turk" entered into American popular culture. It was fueled by Greek and Armenian immigrants from the Ottoman Empire who brought stories of oppression and massacre of the Christian population by the Ottomans, and the enslavement of Christian children in Muslim harems. Together, these images led to casting the Muslim population of the Ottoman Empire as the adversary of Christian civilization and the "Terrible Turk" as an ignorant, barbaric and fanatic figure. ${ }^{13}$ But these popular constructions did not go unchallenged. Some policy-makers and intellectuals argued that the reforms of the Young Ottomans and Young Turks would turn the Empire to a progressive and enlightened path, leading to stability and open trade policies, thus protecting American interests. For example, Samuel Cox, the American ambassador during the reign of Abdulhamid II, wrote in his memoirs: "I have observed...much of the progress of Turkey within the last three decades, and from what I have seen of it I believe that the Turk...can...bring [Turkey]...into the light and liberty of a new civilization." 14 Cox argued that contrary to popular notions, the Turks were honest and fair, democratic, and tolerant, and that "the qualities of patience, candor, contentment and resignation are conspicuous beyond those of any other race." 15 Cox challenged the caricatured image of the Ottoman Empire in the American press, which he described as "strangely anachronous and exaggerative."16

The official view and foreign policy towards the Ottoman Empire carried elements of popular stereotypes, and were shaped by increasing trade and missionary interests. Throughout the nineteenth century, while utilizing the same capitulatory privileges as the Europeans, the United States presented itself to the Ottoman Empire as a trading partner with no territorial ambitions, in contrast to the European Powers. ${ }^{17}$ Stemming from this distinction, and aimed at maintaining an "open door" to prevent European monopolies on trade and investment in the region, American policy-makers preferred bilateral agreements with the Ottoman Government. As American

${ }^{13}$ Roger Trask, "The terrible Turk and Turkish-American Relations in the Interwar Period," Historian, XXXIII (1970), 40-53.

${ }^{14} \mathrm{Cox}$, Diversions of a Diplomat in Turkey, p. 111.

15 Ibid., pp. 176-177.

${ }^{16}$ Ibid., pp. $63-75$

${ }^{17}$ At his first meeting with Sultan Abdülhamid, Samuel Cox told the Sultan "The United States would not, if they could, depart from the invariable policy which forbids all entaglements in foreign affairs, a policy which has signally marked our intercourse, and which has preserved from stress and severance, amidst all vicissitudes, our relations with other Powers." Cox, Diversions of a Diplomat in Turkey, p. 12. 
involvement with the Ottoman Empire increased, growing debate about the Empire in the United States reflected diverse expectation and ambitions, which were challenged with the outbreak of the First World War.

\section{American Policy Towards the Ottoman Empire During World War I:}

As the war began in Europe, the Ottoman Government announced the abolition of the capitulations, thus eliminating extraterritorial rights in the Empire effective October 1, 1914. In Washington, the State Department worried that the abolition of the capitulations would lead to mass imprisonment of foreigners and seizure of foreign-owned property. Some policy-makers also feared that this decision signalled the possibility of other harmful and differential Ottoman policies, leading to the massacre of Ottoman Christians and Christian foreigners in the Empire. ${ }^{18}$ But in the interpretation of some American intellectuals the Ottoman Goverment was "not intent upon [harassing] foreigners, but upon getting rid of an ancient evil," the capitulations, by which Europeans had dominated the Ottoman economy and controlled the Empire's integration into the world market. ${ }^{19}$ Even ambassador Morgenthau, whose memoirs reflect a marked dislike of the Turkish people and suspicion regarding implication of the abolition of the capitulations, expressed agreement with Ottoman leaders, who "had protested for years [against the capitulations], declaring that they constituted an insult to their pride as a nation and also interfered with their progress." 20

As the debate about Ottoman intentions progressed, the United States, along with the European countries, continued to argue that unilateral abrogation of the bilaterally negotiated capitulations was unacceptable. ${ }^{21}$ Maintaining the legal fiction that the capitulations remained in force, American missionaries and educators, businessmen and diplomats continued their activities much as they had before the war. ${ }^{22}$ Also, the official Ottoman posture was to avoid confrontation with the Americans. On the day the capitulation were abolished, the Minister of War, Enver Pasha, made a public visit to Robert College to show the cabinet's support of American activities

${ }^{18}$ Henry Morgenthau, Ambassador Morgenthau's Story, Garden City, N.Y., 1918, pp. 112-120.

${ }^{19}$ Caleb Frank Gates, Not to Me Only, Princeton, 1949, p. 208.

20 Morgenthau, op. cit., p. 113.

${ }^{21}$ For the official American reaction to the abrogation of the capitulations, see United States, State Department, Papers Relating to the Foreign Relations of the United States, 1915 (hereafter, FRUS), Washington, 1924, pp. 1301-1306.

22 American Board of Commissioners for Foreign Missions, One Hundred and Eighth Annual Report, pp. 173-174. 
in the Empire, and Ottoman officials repeatedly assured the Americans that the government would take no actions against American enterprises. 23

Despite the assurances of the Ottoman Government, the abolition of the capitulations seemed to confirm past prejudices and animosities, leading to growing suspicion and hostility in American public and official opinion towards the Ottoman Empire. The memoirs of Henry Morgenthau, the American ambassador to the Ottoman Empire until 1914, clearly reflect this hostility: "Essentially the Turk is a bully and a coward; he is brave as a lion when things are going his way, but cringing, abject, and nerveless when reverses are overwhelming him." 24

In September, 1914, enmity was fueled when the Ottoman ambassador to the United States, Ahmed Rüstem Bey, gave an interview to the Washington Evening Star, in which he criticized American attitudes towards his government, and said Americans had no right to disparage Ottoman treatment of minorities. The ambassador pointed out that American troops had killed thousands of Filipinos who opposed the American conquest of the Philippines at the beginning of the century, and he attacked the treatment of blacks in America. ${ }^{25}$ When the Secretary of State asked for an explanation of his comments, the Ottoman ambassador wrote that "[the] attitude of the press has poisoned public opinion in the United States in regard to the Turkish people to such an extent that a member of that race is seldom thought or spoken of in [America] otherwise than as the 'unspeakable'..."26 The State Department asked Ahmed Rüstem Bey to apologize or be asked to leave the United States, bu he refused to apologize and requested his own transfer. 27

During these years before American entry into the war, relations with the Ottoman Empire remained cool. When the United States entered the war in April, 1917, it declared war only on Germany, but as a German ally, the Ottoman Government severed relations with the United States. The American Government did not declare war on the Ottoman Empire, because it saw

23 Morgenthau, op. cit., pp. 117-120; DeNovo, op.cit., pp. 91-92.

${ }^{24}$ Morgenthau, op. cit., p. 275.

25 Laurance Evans, United States Policy and the Partition of Turkey: 1914-1924, Baltimore, 1965, p. 28; DeNovo, op. cit., pp. 92-93.

${ }^{26}$ Quoted in Evans, United States Policy and the Partition of Turkey, p. 29.

${ }^{27}$ DeNovo, op. cit., p. 93. 
Germany as the main enemy. ${ }^{28}$ President Wilson and American policymakers hoped to limit involvement in the war to the Western front in France, where American troops would participate directly in the effort against Germany. By concentrating on the defeat of Germany, Wilson hoped to shape the post-war settlement in Europe as well as protect American interests in the Black Sea and Mediterranean regions. American planners believed this could best be achieved by avoiding direct involvement in the conflict between the European powers over territorial questions regarding the Ottoman Empire. In addition, the State Department feared that a declaration of war against the Ottoman Empire would lead to retaliation against American missionaries and educators in the Empire, or would provoke mistreatment of the Christian minorities ${ }^{29}$

Within the United States Senate, however, some Republican senators implored President Wilson to expand the war effort to include the Ottoman Empire. Henry Cabot Lodge, Chairman of the Foreign Relations Committee, told the Senate:

"In the days of their success [the Ottoman Turks] were a scourge to Europe and Christendom. In the long centuries of their decay they have been the pest and the curse of Europe, the source of innumerable wars, the executioners in countless massacres...Such a...government as this is a curse to modern civilization. Like a pestilence it breathes forth contagion upon the innocent air. My earnest hope is that among the results of the war...one of the great results I pray for will be the final extinction of the Turkish Empire in Europe." 30

Along with Lodge, Senator William King of Utah was a vocal detractor, and introduced a resolution calling on President Wilson to expand the war effort to include the Ottoman Empire. But Wilson maintained that Bulgaria and the Ottoman Empire were "mere tools [of Germany) and do not yet stand in the direct path of our necessary action." ${ }^{31}$ Thus, by not declaring war on the Ottoman Empire, Wilson and the State Department decided to wait for the struggle which came with the peace.

${ }^{28}$ Wilson's message to Congress regarding war on the Ottoman Empire can be found in Congressional Record, 65th Congress, 2nd Session, Vol. LVI, pt. 1, p. 64, December 7, 1918.

${ }^{29}$ FRUS, 1917, Vol. I, pp. 448-454.

${ }^{30}$ Congressional Record, 65th Cong. 2nd Sess. Vol. LVI, pt. 1, December 7, 1917, p. 64.

${ }^{31}$ Ibid. 


\section{American Views of the Ottoman Empire Following} World War I:

American plans for the post-war settlement were embodied in Woodrow Wilson's fourteen points, which he presented in a speech to Congress in January, 1918. The twelfth point dealt with the Ottoman Empire:

"The Turkish portions of the present Ottoman Empire should be assured a secure sovereignty, but the other nationalities which are now under Turkish rule should be assured an undoubted security of life and an absolutely unmolested opportunity of autonomous development, and the Dardanelles should be permanently opened as a free passage to the ships and commerce of all nations under international guarantees." 32

By reserving for America and the European Powers the right to decide the fate of the Ottoman Empire and the occupants of its territory, Wilson's fourteen points also signalled the administration's intention to pursue an activist foreign policy in Middle Eastern affairs. ${ }^{33}$

In general, Wilson and the State Department believed that after the war, the Berlin-Baghdad axis must be broken to avoid German domination of Central Europe and the Middle East. Breaking the axis required not only defeat of Germany, but the dismantling of the Ottoman Empire. Thus, in the view of American planners, the Turks would maintain control of part of Anatolia, but would lose the control of all territories of the Empire in Europe. This plan required that an independent Armenian Republic would be established in eastern Anatolia, while Arab lands would be placed under some form of European tutelage, creating régimes friendly to the West. Furthermore, to assure freedom of navigation and to eliminate the possibility of a resurgence of the Ottoman Empire, İstanbul and the Straits would be placed under international control. ${ }^{34}$

During the Versailles Conference in 1919, Woodrow Wilson began to consider the possibility of extending American involvement in the Middle East as far as taking on as mandate for an independent Armenia. The largest Christian community in the Ottoman Empire, the Armenians had been the focus of the efforts of the American diplomatic and commercial activities in the Empire. Although Wilson doubted the Senate would support an American mandate in the region, the breakup of the Ottoman Empire now presented the

32 FRUS, 1918, Supplement 1, Part 1, pp. 12-17.

${ }^{33}$ Evans, United States Policy and the Partition of Turkey, pp. 7681 .

${ }^{34}$ Ibid., pp. $72-74$. 
possibility of creating a Christian state in Anatolia on the model of America, with an American-style government and close ties to the United States. American policy-makers also believed that this solution might offer the best protection to the Christians of Anatolia against future offenses that the Americans suspected the Turks would carry out. ${ }^{35}$

With these considerations, Wilson appointed General James Harbord to lead a mission in the Summer of 1919 to examine the condition of the Armenians in Anatolia and the eastern Caucasus. General Harbord was expected to assess the possibilities for an American mandate ${ }^{36}$ Upon his return, Harbord expressed sympathy and concern about Armenians in the region, not only in terms of their relations with the Ottoman Empire but also with Russia. Yet, his final report made clear that an American mandate over an independent Armenia would require a considerable investment of money and manpower. ${ }^{37}$

In the Spring of 1920, during negotiations for the Treaty of Sèvres, the European Powers asked the United States Government to consider a mandate, and requested that President Wilson draw up the boundaries for an independent Armenian Republic. On May 24, 1920 Wilson asked for the support of Congress:

"In response to the invitation of the Council at San Remo, I urgently advise and request that the Congress grant the Executive power to accept for the United States a mandate over Armenia..." I know from unmistakable evidences...that the...United States is looked to with extraordinary trust and confidence, and I believe that it would do nothing less than arrest the hopeful processes of civilization if we were to refuse the request to become the helpful friends and advisers of such of these people as we may be authoritatively and formally requested to guide and assist." 38

${ }^{35}$ Harry N. Howard, The Partition of Turkey: A Diplomatic History, 1913-1923, Norman, Oklahoma, 1931, pp. 231-238.

${ }^{36}$ In his article, Harbord summarizes his mission as being "sent to the Near East to make a study of conditions there with a view to submitting a report which might enable our people to know what would be involved in assuming responsibilities in that region, particularly in the case of Armenia." James Harbord, "Investigating Turkey and Trans-Caucasia," The World's Work, XL (1920), 36.

${ }^{37}$ Harbord's full report is in FRUS, 1919, pp. 841-889. See also, Robert Daniel, "The Armenian Question and American-Turkish Relations, 19141927," Mississippi Valley Historical Review, XLVI (1959), 260262.

${ }^{38}$ United States Congress, House of Representatives, House Documents, Washington, D.C., 1920, 66th Congress, 2nd Session, Vol. 97, p. 3. 
Despite Wilson's request, on June 1, 1920, the Senate voted 52 to 23 against an American mandate for Armenia. ${ }^{39}$ While some Senate members were reluctant to take on a responsibility in what they considered "a far off land," others rejected the mandate over Armenia in support of an independent Armenian Republic. Among the American public, the Senate's rejection of the mandate was supported by those who opposed an American mandate both for Armenia and the Ottoman Empire, and especially a group of prominent Americans who had joined together in 1918 to form the American Committee for the Independence of Armenia. ${ }^{40}$ The Committee argued that instead of taking a mandate over Armenia, the United States should recognize its full independence and extend diplomatic and military assistance against the Turks. Labeling the developing Turkish nationalist movement as a panTuranist movement in disguise, the organization argued that "the creation of an Armenian state that will unite Ararat with Cilicia...alone can become an effective barrier against the pan-Turanian ambition of the Turks of Anatolia." 41

News in America regarding the Turkish nationalist movement, Mustafa Kemâl and the government of Ankara was colored by existing images of the "Terrible Turk:" bloodthirsty and fanatical. Many in America saw the post-war Allied oocupation of Ottoman territory as a way to protect the Christian minorities, and applauded separatist movements from the Ottoman Empire. They were equally convinced that the aims of the Turkish nationalists included massacre of Armenians and other Christians along with American missionaries. 42

In early 1919, Woodrow Wilson appointed the commander of the American fleet in the Mediterranean, Admiral Mark Bristol, as High Commissioner in Turkey. This appointment followed the Allied decision to restore trade relations with the Ottoman Empire, and came about the same time as the Harbord mission to Armenia. Like Harbord's, High

${ }^{39}$ Edgar W. Turlington, The American Treaty of Lausanne, Boston, 1924 , p. 577.

${ }^{40}$ The executive committee of the American Committee for the Independence of Armenia included James W. Gerard, ex-ambassador to Germany, Charles Evans Hughes, later Secretary of State, Alfred E. Smith, Governor of New York, and Senator Henry Cabot Lodge, among others. See American Committee for the Independence of Armenia, The Joint Mandate Scheme: A Turkish Empire Under American Protection, New York, 1920.

41 Ibid., p. 5.

${ }^{42}$ See for example, Senate debate in 1919 and 1920, in Congressional Record, 66th Congress, 1st Session, Vol. LVIII, part 7, pp. 7050-7054, and Congressional Record, 66th Congress, 2nd Session, Vol LIX, part 4, p. 3792. 
Commissioner Bristol's duties were to look after American interests in the area and to report on the situation in the Empire. In March, 1920 Bristol sent a telegram to the State Department criticizing attempts to dismember the Ottoman Empire for the benefit of the European Powers without regard for the wishes of the Empire's inhabitants. Bristol attacked policies that concentrated on:

"the suppression or distortion of all information favorable to the Turks or giving the Turkish viewpoint, [while]...giving the greatest publicity to all information unfavorable to the Turks as well as exaggerating the evil characteristics of the Turks... [and] misrepresentation of the Nationalist movement of Mustafa Kemâl as a Union and Progress organization controlled by Enver and his followers for a concerted attack against Christian races." 43

Bristol became an early advocate of better relations with the Turkish nationalists. Overall, Bristol called American policy in the Middle East "too hidebound and conservative" and argued that the rapidly changing circumstances demanded a more flexible policy to counter European attempts to exclude American interest from the region. ${ }^{44}$ According to Admiral Bristol, his new policy would require a new approach to the Turkish nationalist movement as well as reconsideration of images of Turks as a whole. In reaction to the Methodist Bishop James Cannon, 45 who asked the American Government to protect Christians from the Turks, Bristol told the Bishop that his petition:

"was undoubtedy based upon a misconception of the real conditions...in the Middle East...I laid great emphasis upon the fact that in my opinion there has been spread in America an entirely wrong impression of the situation in the Near East and that our relief committees and missionaries, as well as propaganda press of the Greeks and Armenians, have lent themselves to imparting this wrong information." 46

The views of Admiral Bristol were shared by Admiral Colby Chester, the representative of a group of American businessmen seeking a commercial concession from the Ottoman Government. After returning from a trip to

${ }^{43}$ Dispatch, March 30, 1920, in Mark Lambert Bristol Papers, Library of Congress, Washington, D.C., Box 72 .

${ }^{44}$ Ibid.; see also, DeNovo, American Interests and Policies in the Middle East, p. 131.

${ }^{45}$ The Methodist Bishop James Cannon arrived in Istanbul in September, 1922 on his own mission of concern for the Christians. He showed Bristol a petition to the American Government asking it to protect Christians from Turkish persecution. DeNovo, op. cit., pp. 133-134.

${ }^{46}$ Bristol Papers, Box 21. 
Istanbul in 1922, Chester wrote: "[T]he wrong impression of the Turks was spread because their religious belief is different from ours. That and that alone lay at the bottom of the prejudice of America against the Turk." 47

Chester continued, calling on American businessmen to examine the opportunities in Turkey: "Returning, I feel that I have come from the most wonderful country in the world, the country which offers the greatest opportunities to the American businessman. The Turks need almost everything which America can wish to sell to them, and they are the best of people to deal with." 48

The arguments of Bristol and Chester regarding the Ottoman Empire and the Turkish nationalist movement challenged the traditional opposition centered on the image of the "Terrible Turk." Yet their call for change in policy in response to the Turkish nationalist movement did not alter the State Department's objectives in the region: restoration of the capitulations and protection of American trade and investment, as well as missionary activities and Christians in the region. Throughout the period after World War I, the State Department continued to reject the "illegal interference of the [Ottoman] government in the application of the capitulations," 49 and maintained efforts to restore the capitulations in the hope of preventing the taxation or seizure of American property and commerce, the arrest and trial of Americans by Turkish courts, and the imposition of higher tariffs on American goods. ${ }^{50}$ The acknowledgement of the nationalist government in Ankara only led the State Department to expect both the İstanbul and Ankara governments to reinstate the capitulations.

The capitulations were an American policy objective agreed upon by both interventionists and isolationists, who were locked in a domestic power struggle after the First World War, regarding the future of American foreign policy. The Senate's rejection of the treaty of the League of Nations in 1919, followed by its rejection of the mandate for Armenia, confronted President Wilson's call for a more active and interventionist American foreign policy. This reaction reflected sentiment in favor of more limited American involvement in world affairs, signalling the dominance of the isolationists.

The final blow to Woodrow Wilson's interventionist foreign policy came with the victory of the Republican Party and the election of Warren Harding as President in 1920. After 1920, the American Government

${ }^{47}$ Colby Chester, "Turkey Reinterpreted," Current History, XVI (1922), 939.

48 Ibid., p. 942.

${ }^{49}$ FRUS, 1919, Vol. II, p. 815.

${ }^{50}$ FRUS, 1920, Vol III, pp. 757-766; FRUS, 1921, Vol. II, pp. 890-916. 
remained aloof in the struggle between the nationalist government in Ankara and the Ottoman Government and Sultan in Istanbul, and in the war between the nationalist and foreign occupation armies in Anatolia. When the Greek armies were driven out of Izmir in September 1922, the American fleet did nothing beyond trying to protect American tobacco warehouses from the fire that consumed the water front.

\section{The United States and the Lausanne Conference:}

In October 1922 the European Powers announced an invitation to the nationalist Government of Ankara, as well as to the Ottoman Government of Istanbul to negotiate a settlement at Lausanne, Switzerland. ${ }^{51}$ As the head of the Turkish delegation, the Ankara Government decided to send İsmet Pasha, who had served as Commander of the Western Armies in the War of Independence, and successfully negotiated the armistice at Mudanya on October 11, 1922. The Turkish delegation also included Minister of Health Riza Nur Bey and the former Minister of Finance Hasan Bey (Saka), along with more than twenty military, financial and legal advisers. Beside Turkey, Great Britain, France and Italy, representatives of Japan, Greece, Rumania, Yugoslavia, Soviet Russia, the Ukraine and Georgia also announced their intention to participate in the conference. ${ }^{52}$

When the European Powers invited the United States to participate in the negotiations, the Americans responded that "the United States was neither at war with Turkey nor a party to the armistice of 1918 and does not desire to participate in final peace negotiations or to assume responsibility for the political and territorial adjustments which may be effected." 53 The United States wanted to limit its involvement, yet was concerned about the impact of negotiations at Lausanne on American interests in the Middle East. In early October 1922, Bristol wrote to Charles Evans Hughes, the Secretary of State: "As the United States is one of the capitulatory powers with extensive vested interests in Turkey, we cannot afford to remain inactive while the

\footnotetext{
${ }^{51}$ The dual invitation precipitated a decision by the nationalist government of Ankara to abolish the Sultanate and declare itself the sole representative of the Turkish people. For discussion of this turbulent era, see Ismet Inönü, Hatıralar [Memories], Vol. II, Ankara, 1987, pp. 43-50; Mustafa Kemâl Atatürk, A Speech, Ankara, 1981, pp. 568-588; Roderic Davison, "Turkish Diplomacy from Mudros to Lausanne," in G. Craig and F. Gilbert, eds., The Diplomats, 1919-1939, New York, 1972, pp. 198-200.

52 Mehmet Gönlübol and Cem Sar, "1919-1938 Yılları Arasında Türk Dı̧ Politikası," in A. Suat Bilge, et. al., Olaylarla Türk Dış Politikası: 1919-1965 [Turkish Foreign Policy with Events], 2nd ed., Ánkara, 1969, pp. 53-54.

53 FRUS, 1923, Vol. II, p. 884.
} 
Allies give their consent to important changes in the capitulatory regime." 54 As a result of these concerns, the State Department took three steps to assure the protection of American interests. First, the United States sent observers to the conference to make certain American interests were not adversely affected by the negotiations. Second, it presented the European Allies with a list of American interests and concerns in the negotiations, and third, the United States announced its intention to negotiate a separate treaty with the new Turkish Government, at an appropriate time. ${ }^{55}$

The list of American concerns and interests presented to the European Powers formed the basis of American activities at the Lausanne Conference, and served as the foundation of negotiations for the separate treaty with the new Turkish Government. The State Department listed seven issues, including the maintenance of the capitulations; the protection of American philanthropic, educational and religious institutions; an "open door" for commercial enterprises; indemnity for losses suffered by Americans during the war; provisions for the protection of minorities; assurances of the freedom of the Straits, and opportunity for archeological research. 56

The capitulations would prove to be among the most intransigent issues at the Lausanne Conference. Although the State Department anticipated that the Turkish negotiators would resist restoration of the capitulations, especially on economic grounds, it was determined nevertheless to insist upon "the retention of the capitulations which are essential to the protection of American citizens." 57 The State Department also believed that the capitulations were necessary to protect the welfare of the Greeks and Armenians, and was convinced that American public opinion would demand that the treaty provide international protection of the Christians. In March 1923, an official in the Division of Near Eastern Affairs of the State Department wrote:

"If, in negotiating the treaty with Turkey, we leave out all considerations of a purely ethical nature, we must be prepared to take the conequences...[B]y dealing with the Turks as though nothing had happened, by appearing eager to shake hands with them...without taking into consideration American public opinion, we might lay ourselves open to criticism which it would be difficult to answer." 58

54 Ibid.

$55_{\text {Ibid., p. } 886 .}$

56 Ibid., p. $884,899$.

57 Ibid., p. 886 .

${ }^{58}$ United States, State Department Files (hereafter USSD), Division of Near Eastern Affairs Memo, March 14, 1923, USSD 711.672/17. 
But the issue of protection of Christians was not easily resolved. The State Department had no clear evidence that the nationalist Government of Ankara had abused the Christians, or that it would do so in the future. Ismet Pasha, leader of the Turkish delegation, assured the participants at Lausanne that the new Turkish Government guaranteed protection of the lives and property of all citizens. Ismet Pasha was also unyielding in the position that the new government would not allow restrictions on its sovereignty, or interference in domestic and foreign affairs.

In the State Department's complex agenda, the protection of Christians coincided with, and also legitimated, the protection of American investments and economic interests. In particular, the American delegation at Lausanne was intent on preserving privileges and opportunities for American commerce and investment equal to those obtained by the European Powers. Throughout the conference, and in direct negotiations with the Turkish delegation, the American diplomats insisted on the principle of the "open door" economic policy and most favored nation status in trade and tariffs, along with the protection of Christians. ${ }^{59}$ But the main objective of the American team emerged as preventing the European Powers from establishing monopolies to the detriment of American interests in the region, while reaching an accord with the new Turkish Government to assure access to markets and investments in the Middle East. ${ }^{60}$

The negotiations at Lausanne were carried out in two phases, from November, 1922 to February, 1923 and April, 1923 to August, 1923. When the conferece opened on November 20,1922, the United States was represented by Richard Child, Ambassador to Italy, Admiral Mark Bristol, High Commissioner to Turkey and Joseph Grew, Minister to Switzerland. ${ }^{61}$ During the first phase of the conference the American and Turkish delegations carried on informal negotiations for a separate treaty. During the second phase of the conference, Joseph Grew led the negotiations for the United States. ${ }^{62}$

59 Joseph Grew, Turbulent Era: A Diplomatic Record of Forty Years, 1904-1945, Boston, 1952, Vol. I, pp. 500-501, 506-511.

${ }^{60}$ Turlington, American Treaty of Lausanne, pp. 582-583. Turlington was a member of the American delegation at Lausanne.

${ }^{61}$ After the opening ceremonies on November 20,1922, Grew wrote in his diary, "At sundown tonight I looked out of my window and saw the new moon, looking remarkably like a Turkish crescent, hanging directly over the tower of the Hotel du Chateau where the Peace Conference is to take place. Was it an omen? We shall learn eventually." Quoted in DeNovo, American Interests and Policies in the Middle East, p. 128.

62 Joseph Grew had served in the American foreign service for nearly two decades in Cairo, Mexico, St. Petersburg, Berlin, Vienna and at the Paris Peace Conference after World War I. See Grew, Turbulent Era, Vol. I, pp. 
After the conference resumed in April, Ismet Pasha suggested on May 5th that formal negotiations begin for a treaty to restore normal diplomatic and commercial relations. ${ }^{63}$ Grew later recounted in his memoirs:

"As for Ismet Pasha, my opinion of him underwent several changes during the course of the conference, but my final judgement is that, while lacking any of the adaptability or finesse of his opponents, he played a straight and honest game throughout...After all, in Ismet's position, it was the bluff qualities of the soldier and not the subtlety of the old-school diplomat which he needed and which he exercised throughout." 64

When the final draft of the Lausanne Treaty between the Turkish Government and the European powers was prepared, the Americans, although formally discussing a separate treaty, reconsidered whether or not they should add their signature to the multilateral agreement. While they felt that signing the treaty would assure America of the same rights and privileges as the Europeans, it could also obligate the United States to police the Straits, and take responsibility for the Christians in Turkey as part of European designs in the Middle East. Fear of uncertain obligations, along with the Senate's rejection of the multilateral Versailles Treaty in 1919, convinced the State Department to decline signing the Lausanne Treaty of July $24,1923.65$

After the completion of the Lausanne Treaty, Joseph Grew and İsmet Pasha remained in Lausanne to complete the details of the separate treaty between the United States and the Government of Ankara. Within two weeks, all the outstanding details were agreed upon, and on August 6th the Treaty of Amity and Commerce was signed by the two statesmen. Actually, the treaty was substantially the same as the Lausanne Treaty. ${ }^{66}$ With this agreement,

475-605; also, Joseph Grew, "The Peace Conference of Lausanne, 1922 1923," Proceedings of the American Philosophical Society, 98 (1954), 1-10.

${ }^{63}$ Inönü, Hatıralar, Vol. II, pp. 150-151.

${ }^{64} \mathrm{Grew}$, "Peace Conference of Lausanne," pp. 5-6. In a letter to his father-inlaw at the time, Grew was even more effusive in his praise: "Ismet is Napoleonic - the greatest diplomatist in history. He has played every one of us to a standstill. And he has done it fairly and squarely, all growls to the contrary notwithstanding. I have great admiration for him and personal respect. He is a very great man." Quoted in DeNovo, American Interests and Policies, p. 151.

${ }^{65}$ Turlington, American Treaty of Lausanne, pp. 590-591.

${ }^{66}$ For a comparison of the two treaties, see "Peace Terms with Turkey," Current History, XIX (1923), 89-99, and "The Turco-American Treaty," Current History, XIX (1923), 100-101. In his memoirs, 1smet Inönü wrote that even though the American Government resisted accepting the Lausanne Treaty as it was negotiated with the European Powers, it was 
along with the European countries, the United States recognized the abolition of the capitulations and their substitution by a new commercial, legal and diplomatic framework. The treaty, along with official statements by Ismet Pasha concerning the protection of American missionary and educational institutions and the ongoing changes in the administration of justice in Turkey, met all of the concerns expressed by the State Department at the beginning of the Lausanne Conference. ${ }^{67}$

For Europe, "the Lausanne Treaty announced peace to the world," as voiced by the President of Switzerland in his closing speech to the Conference. ${ }^{68}$ For Turkey the Lausanne Treaty meant formal acceptance of the new Turkish Government by the European Powers. Moreover, acceptance of the Lausanne Treaty by the Turkish Grand National Assembly reflected legitimization of Atatürk's government in international as well a domestic affairs. İsmet İnönü framed this tension in Turkey regarding the Lausanne Treaty as the conflict developing in the aftermath of the battle, which reflected existing tension within the Turkish Assembly and Atatürk's government. 69

The Treaty of Amity and Commerce was meant to be the foundation of normal diplomatic and commercial relations between the newly established Government of Turkey and the United States. For the Turkish delegation, and Inönü, the agreement with the United States had a lesser importance in comparison with the Lausanne Treaty. Inönü describes the American actions during the conference as friendly and helpful, yet guarded and concerned with protecting their interests. The American posture fit with the Turkish vision of the United States as a distant and amicable power. According to İnönü, when Grew approached him to establish a relationship with Turkey, Inönü felt he could extend the same terms to America as contained in the Lausanne Treaty with the Europeans, in order to normalize Turkish foreign relations. ${ }^{70}$

willing to accept an altered version that Inönü proposed. According to Inönü, the second version was the text that the Turkish delegation brought as the Turkish Government's original proposal to Lausanne. Inönü points out that the difference between the two treaties was a difference of words, not even sentences. Inönü, Hatıralar, Vol. II, p 151. According to Joseph Grew, who wrote to Secretary Hughes "it was we [the American delegation] who laid the original draft treaty before the Turks." Grew, Turbulent Era, Vol. I, p. 601. Despite the apparent disagreement on the origins of the treaty, the final product was very close to the Lausanne Treaty. Its major distinction was that while the American-Turkish agreement was bilateral, and bound the sides as such, the Lausanne Treaty was a multilateral agreement.

${ }^{67}$ Turlington, American Treaty of Lausanne, pp. 592-595.

${ }^{68}$ Quoted in Inönü, Hatıralar, Vol. II, p. 312.

${ }^{69}$ Inönü, Hatıralar, Vol. II, p. 148.

${ }^{70}$ Ibid., p. 150. 
In Turkey the treaty with America was ratified as a matter of course, along with the Lausanne Treaty. But in the United States, the treaty immediately met with a storm of protest from critics of the treaty and opponents of relations with Turkey. It also brought new voices to the surface in support of relations with the newly established Turkish Government.

\section{The American Debate on Relations with Turkey: Opponents and Proponents:}

Joseph Grew was apprehensive about the treaty. In a letter to Secretary of States Charles Evans Hughes on the day of the signing, he wrote: "The Treaty...is far from what I should have wished to have it. It represents a considerably greater number of concessions on our part...than...on their part." 71 Following the signing of the treaty, Grew also anticipated conflict and opposition: "There were still in our country elements which were dissatisfied that I had not been able to pull impossible rabbits from impossible hats. I was openly accused in the United States Senate of having sold my nation's birthright for a mess of pottage."72

Opposition was not new, and its now solidified argument contested the government's initiative to establish relations with Turkey under the terms of the treaty. Thus, partly due to the sudden death of President Warren Harding, and especially in anticipation of strong opposition in the Congress, the treaty was not submitted to the Senate for nine months. Actually, the debate over the treaty, and controversy over terms of the relations with Turkey, lasted another three years, until 1927.

Opponents of the treaty in the Senate, as well as among the public, concentrated their criticism in three main arguments. The first was that the treaty did not obtain all it could or should have from the Turkish side, in particular restoration of the capitulations. Opponents accused Joseph Grew and the State Department of being "soft" on the Turks and not forcing the Turkish Government to make more concessions. The second issue raised by opponents was that the treaty contained no specific clause to guarantee the protection of Christians in Turkey, or allowances for foreign intervention on their behalf. Related to this, opponents raised a third issue. They maintained that the treaty protected commercial interests at the expense of what they saw as America's moral obligation to the Christians.

Proponents argued that the Turkish-American treaty secured the same rights for the United States as the Lausanne Treaty allowed to the European Powers, thus more favorable terms could not have been obtained.

${ }^{71}$ Grew, Turbulent Era, Vol. I, p. 601.

${ }^{72}$ Grew, "Peace Conference of Lausanne," p. 2. 
Furthermore, they argued that the only way for America to protect Christians was by force, contrary to isolationist foreign policy sentiments, and requiring a costly military commitment in the region. Proponents also maintained that the treaty protected the legitimate interests of all Americans and American institutions in Turkey, not only commercial enterprises.

On the side of the debate supporting ratification of the treaty were prominent members of the State Department, including Secretary of State Charles Hughes and his successor Frank Kellogg, along with Joseph Grew and Mark Bristol. In the Senate, supporters were led by Senator William Borah, who became Chairman of the Foreign Relations Committee in 1925. Outside the government, American businessmen and organizations that had interests in Turkey supported the treaty, as did American missionary and educational groups with institutions in the Middle East. Among the leading opponents were Henry Morgenthau, former ambassador to the Ottoman Empire, and Senators William King and Claude Swanson. In addition, the opposition outside the government included a group of Protestant Episcopal bishops, and a number of private citizens and diverse groups who opposed establishing relations with Turkey for political reasons. Public opposition was voiced by James Gerard, former ambassador to Germany, David Hunter Miller and Vahan Cardashian, a lawyer from New York City. Gerard, Miller and Cardashian formed the Committee for the Independence of Armenia in 1918, and in 1923, they founded the Committee Opposed to the Lausanne Treaty.

Opponents of the treaty were ready, and quickly launched a campaign to sway public opinion, in the expectation that public pressure would lead the Senate to reject the treaty. Their campaign included books and pamphlets, protest meetings and letter writing campaigns. For example, The American Committee for the Independence of Armenia reported that by the Spring of 1922 it had already distributed 246.500 copies of 321 different pamphlets, mailed 17.000 personal letters and telegrams, and mass mailed 173.000 letters. According to the report, on one occasion, the Committee distributed pamphlets to 116.000 churches, asking them to write to the President and to Congress in favor of Armenian independence. The Committee had also secured the names of 20.000 ministers and priests, 250 college presidents in favor of Armenian indenpendence, during the Allied occupation of Anatolia and the Turkish War of Independence. ${ }^{73}$ When the Turkish-American treaty was signed at Lausanne, the Committee expanded its efforts to fight against establishing relations with Turkey as well as terms of the Lausanne Treaty. The efforts of the American Committee Opposed to the Lausanne Treaty played an important role first in delaying consideration of the treaty, and in its ultimate rejection by the Senate.

${ }^{73}$ Untitled pamphlet from the American Committee for the Independence of Armenia, April 14, 1922, USSD 711. 672/382 1/2. 
The debate following the signature of the treaty in Lausanne showed considerable continuity wih the pre-war discussions in America about the Ottoman Empire and about American policy in the Middle East. For example, James Gerard, emphasizing the image of the "Terrible Turk," wrote to Secretary of State Hughes in November, 1923 that he had the assurances of a number of Senators of both parties that they were "hostile to the treaty" because it did not protect Christians in Turkey, and the Turks could not be trusted to honor their obligations. Gerard argued that since the Senate would certainly reject the treaty, it would "be more dignified [for the State Department] to denounce the treaty" immediately, and refuse to establish relations with Turkey until it recognized the independence of an Armenian state in Anatolia. ${ }^{74}$

Gerard's position also represented a belief shared by many opponents of the treaty that American refusal to enter into relations with Turkey could force changes in the region, or at least would have a decisive impact on the foreign and domestic policies of the new Turkish Republic. Their initiative reflected a conviction in American foreign policy as a force for "morality" in international affairs, therefore America's special duty to protect Christians against Muslims in the Middle East. Furthermore, they feared economic considerations were overshadowing this mission and they accused the State Department of catering to commercial interests, in particular the Chester Concession, which included oil exploration in eastern Anatolia. ${ }^{75}$ For example, in December, 1923 a group of private citizens in Philadelphia, organized as the Society for Justice in the Near East, issued a statement attacking the State Department and the treaty, saying it was "smeared all over with oil and blood."76

The complexity of the discussion derived from the issue of "morality" in the making of American foreign policy. While opponents argued that it was America's moral obligation to reject the treaty, proponents were equally convinced that without the treaty, America could not exert moral influence on Turkey. Also, proponents of the treaty pointed out that the multilateral Lausanne Treaty declared the European acceptance of the independence of

${ }^{74}$ Letter from Gerard to Hughes, November 19, 1923, USSD 711. 672/207.

${ }^{75}$ Following the resumption of trade relations with the Ottoman Empire in 1919, Admiral Chester returned to Istanbul to revive claims for economic concessions in eastern Anatolia with a new project that would include oil exploration. Admiral Chester requested, and received, support from the American Legation in Istanbul, which led to accusations that the State Department was concerned only with the profits of a few American companies. DeNovo, American Interests and Policies in the Middle East, pp. 210-228.

${ }^{76}$ Letter from Leinbach to Hughes, December 3, 1923, USSD 711. 672/234. 
Turkey and the sovereignty of the Turkish Government over its domestic affairs. Thus, refusal of the United States to accept Turkey would reduce American influence in the region, relative to the European Powers. In addition, supporters maintained that since the Europeans accepted the abolition of the capitulations, the United States could not obtain privileges denied other countries in the making of Turkish foreign and domestic policy, which would also be interpreted by the European Powers as a hostile intervention in the region. On these lines, supporters argued that since the Lausanne Treaty made no provision for the concept of an independent Armenia, the United States could not force its acceptance.

In January, 1924 Secretary of States Hughes addressed the Council on Foreign Relations in New York. In defense of the treaty, Hughes argued: "The Lausanne Treaty is such a treaty as would be negotiated with any other sovereign state,...it gives us the same rights as other countries will enjoy under the new regime, and...by regularizing our relations with Turkey, now interrupted for nearly seven years, it will provide safeguards for American educational, philanthropic and commercial interests in Turkey." ${ }^{77}$

Hughes maintained that "at no stage in the negotiations was the American position determined by the so-called Chester concession," 78 refuting the charges of opponents of the treaty, in particular James Gerard and Senator King. Hughes insisted that the State Department sought only to protect legitimate American interests in Turkey, and was not swayed in its considerations by economic matters.

Hughes' speech in New York was part of an effort launched by the State Department in the Fall and Winter of 1923-1924 to inform Senators and the public of its view of the benefits of normalizing relations with Turkey. In this framework, Allen Dulles, Chief of the Division of Near Eastern Affairs of the State Department, suggested that the department should prepare reports on the events leading to the treaty, in order to answer criticism. ${ }^{79}$ Admiral Bristol also began collecting statements from Americans in Turkey supporting the treaty. Among them was Caleb Frank Gates, President of Robert College in Istanbul, who argued that the treaty did not condone the actions of the Ottoman Government, but merely normalized relations between the United States and the newly established Turkish Republic. ${ }^{80}$

77"An Address by the Honorable Charles E. Hughes before the Meeting of the Council on Foreign Relations," pp. 13-14, included in USSD 711. $672 / 287 b$. 78 Ibid.

${ }^{79}$ Dulles to Hughes, October 13, 1923, USSD 711. 672/229.

${ }^{80}$ Statement by Caleb Frank Gates, April 1, 1924, USSD 711. 672/275. 
The State Department also sought the support of American academics, such as Albert Lybyer, a professor at Illinois University, and scholar of Ottoman history. Lybyer publicly debated Albert Bushnell Hart of Harvard University at a meeting of the Chicago Council on Foreign Affairs, and volunteered to testify before the Senate in favor of establishing relations with Turkey. ${ }^{81}$ Academic discussion of the treaty reached a height when the journal Forum published a debate in 1924, between Albert Bushnell Hart and Edward Meade Earle of Columbia University. Hart argued that the Turks were "barbarous people whose government is oppression, whose tax system is plunder, and whose idea of war is torture, fire and blood." According the Hart, the very idea of a treaty with Turkey was unthinkable: "When the real character of the so-called Turkish nation is made clear, and when the weakness of the foundations of the Treaty is exposed, then no arguments that it is favorable...have any weight, because [Turkey] is not a sound, permanent and responsible nation." 82

Earle, on the other hand, castigated opponents of the treaty:

"Our Turcophobes, amateur and professional, insist that ratification of the treaty would be a humiliating spectacle, -a great, powerful America ignobly bowing before a puny and anaemic Turkey; a generous Christian government extending the hand of friendship to a 'government of murderers', the American Senate placing its stamp of approval upon the Armenian massacres. This conception of the importance of the Turkish Treaty exhibits a warped, if not frenzied, perspective." 83

Earle pointed out that the treaty was not designed to remake history, but merely to establish normal relations between the United States and the Turkish Republic. Earle continued to argue that opponents of the treaty were hypocritical:

"In every thousand persons, who assert that national minorities and foreigners will not obtain justice in Turkish courts, it would be difficult to find one who does not pass over in silence the fact that Negroes enjoy little protection from court in the South, and that there is no such thing as judicial impartiality toward the Japanese on the Pacific coast...It is not necessary to multiply illustrations of our willingness -nay, our eagerness- to mete out one

${ }^{81}$ Letter from Lybyer, April 1, 1924, USSD 711. 672/281.

${ }^{82}$ Albert Bushnell Hart, "Making Friends with Unrighteousness," The Forum, LXXII (1924), 735.

${ }^{83}$ Edward Meade Earle, "Our Holier-Than-Thou-Policy," The Forum, LXXII (1924), 740. 
measure to the Turks, another to other peoples, and yet a third to ourselves." 84

As the State Department rallied support for its position, its efforts brought into focus sharp differences. After all, the debate about relations with Turkey and the terms of the treaty was not only about Turkey, it was becoming increasingly a platform for the expression of opposing views of the meaning of America, and commitment and mission in its domestic and foreign policies. And most importantly, this discussion became a way to debate options for the future of the United States in world affairs.

\section{The Battle in the Senate Over Relations with Turkey:}

In May, 1924 President Calvin Coolidge submitted the TurkishAmerican treaty to the Senate for its consideration, which intensified the activities of both its opponents and proponents. The Committee Opposed to the Lausanne Treaty published new pamphlets, entitled "The Lausanne Treaty and Kemalist Turkey," and "The Senate Should Reject the Turkish Treaty," declaring that the "honor of America demands [its] rejection." The pamphlets derided Mustafa Kemâl as a military despot, and called the treaty "utterly humiliating and purposeless." According to the Committee, the United States had surrendered all of its rights and abandoned the Christians to a despotic, corrupt and barbaric state ruled by enemies of civilization. 85

In August, 1924 Admiral Bristol, High Commissioner in Istanbul, wrote to the Secretary of State specifically to refute "the many inaccuracies" in the accusations made by the Committee Opposed to the Lausanne Treaty. Bristol argued that the pamphlets published by the committee suffered from a "general tone of inaccuracy and exaggeration." $86 \mathrm{He}$ maintained that the treaty was necessary to protect American interests in Turkey, and that it was basically no different that dozens of other treaties the United States had contracted with other sovereign states, without popular debate or opposition..$^{87}$ Bristol's call for ratification of the treaty to protect American interests was supported by Herbert Hoover, the Secretary of Commerce, and later president after Calvin Coolidge. In a letter to the Secretary of State, Hoover called attention "to the importance, from the viewpoint of American commerce, of the prompt ratification of the treaty with Turkey..." ${ }^{88}$ Hoover argued: "Until a treaty with Turkey is ratified by the United States, the benefits of any concessions or privileges established by Turkey in favor of

${ }^{84}$ Ibid., p. 741.

85 Morgenthau Papers, Reel 32.

${ }^{86}$ Letter from Bristol to Hughes, August 9, 1924, USSD 711. 672/312.

87 Ibid.

${ }^{88}$ Hoover to Secretary of State, December, 1924, USSD 711. 672/335. 
any of the treaty countries under the new régime may be denied to the United States and its nationals...Should the disposition of this treaty be postponed until the next session of Congress, a year hence, increasing handicaps may be imposed on American commerce with Turkey." 89

Hoover's efforts in favor of the treaty were followed up by visits to Senators by Allen Dulles, of the Division of Near Estern Affairs. In his talks, Dulles stressed "the importance of the treaty not only for the protection of our trade but for the protection of our schools and other philanthropic enterprises in the Near East." Dulles also pointed out that Turkey-was strategically important to the United States: "The possession of the Straits gave it added importance from the point of view of American trade and commerce and the provision in our treaty for passage through the Straits for our ships of commerce and of war was of great significance." 90

In February, 1925, the Senate Foreign Relations Committee, chaired by Senator William Borah, an established supporter of the treaty, reported favorably and sent it to the Senate for a full vote. But two weeks later, the treaty was sent back to the Foreign Relations Committee after a test vote revealed the treaty did not have sufficient support for ratification. The treaty remained in committee for another year before the Foreign Relations Committee again voted in favor and returned it the Senate. But in early July, 1926 Borah proposed that the vote on the treaty be postponed until after the congressional elections, thus delaying Senate debate until the first day of the new session in January, 1927.

The delay in the vote on the treaty gave opponents and proponents time for a final effort. The Committee Opposed to the Lausanne Treaty published a new pamphlet, entitled "Kemal's Slave Market and the Lausanne Treaty." The pamphlet maintained that between 100.000 and 400.000 Christian girls and children were being held in slavery in Turkish harems, being sold into captivity by the Kemâlist government, and issued a plea: "We think of a multitude of white Christian women, girls and children, helpless in the hands of Moslem owners -unable to escape from Moslem bondagesubject to foul indignity and bestial brutality...We think of refined, educated, Christian girls in the power of the unspeakable Turk."91

At the same time, Joseph Manning, episcopal bishop of New York, told a meeting of the Girls' Friendly Society that 100.000 Christian girls were being held in Turkish harems. ${ }^{92}$ In the Spring of 1926, Manning led

\footnotetext{
${ }^{89}$ Ibid.

${ }^{90}$ Memo by Dulles, February 13, 1925, USSD 711.672/347 1/2.

91 Morgenthau Papers, Reel 33.

92 Bristol to Manning, May 20, 1926, USSD 711. 672/475.
} 
110 Episcopal Bishops in presenting a petition to the Senate, stating that "the Christian sentiment of America is opposed to the ratification of the Lausanne Treaty, in its present form." 93

Despite the growing opposition, State Department officials maintained their position. Acknowledging opposition to the treaty, Admiral Bristol wrote in January, 1926 that ratification of the treaty would simply afford a means of protecting legitimate American interests, but did not require condoning past Ottoman actions or approval of the new régime: "We ask for ratification simply because we cannot see why perfectly tangible American interests in Turkey should not receive that measure of proper and normal support which our government extends to similar American interests in other parts of the world."94 Allen Dulles also believed the treaty would increase American influence in Turkey, and did not restrict America from taking action in the future on behalf of the Christians. ${ }^{95}$ In March, 1926 Dulles summarized seven points in favor of ratification: (1) the treaty enabled the United States to protect American interests in Turkey; (2) Americans in Turkey wanted the treaty ratified; (3) American activities were being conducted on an unsatisfactory basis without treaty protection; (4) opinions about Turkey had nothing to do with the need for a treaty; (5) Americans were at any rate unwilling to use military force to protect the rights of Armenians; (6) the treaty would help America's trade with the Black Sea region; and (7) ratification of the treaty did not condone the Ottoman past or the present régime. ${ }^{96}$ Joseph Grew also urged that the treaty would increase America's positive influence in Turkey, and America's influence would decrease without the treaty. ${ }^{97}$ In May, 1926 Secretary of State Frank Kellogg argued that Turkey had a new government and a modern legal system, and that the new government was not the same as the Ottoman régime, thus the changes in Turkey should be recognized and supported by ratification of the treaty. 98

By late 1925 and early 1926, businessmen, missionaries, and educators, along with private citizen groups who had direct dealings with the new Turkish Republic and interests in Turkey joined the State Department

\footnotetext{
${ }^{93}$ The petition was presented to Senator Claude Swanson of Virginia, a vocal opponent of the Treaty. Morgenthau Papers, Reel 32; see also New York Herald Tribune, April 5, 1926.

${ }^{94}$ Bristol to Secretary of State, January 19,1926 , USSD $711.672 / 391$.

95 Letter from Dulles to Hibben, February 6, 1926, USSD 711.672/393.

96 Memo by Dulles, March 26, 1926, USSD 711. 672/410a.

97 Letter from Grew to Slattery, April 7, 1926, USSD 711.672/417 1/2.

${ }^{98}$ Letter from Kellogg to Kelsey, May 14, 1926, USSD 711.672/465.
} 
effort and began to rally in support of the treaty. ${ }^{99}$ James Barton, secretary of the American Board of Commissioners for Foreign Missions and the head of Near East Relief, played an important role in representing the support of missionaries. Barton had attended the Lausanne Conference with the intention of working for the restoration of the capitulations, but quickly became convinced that the missionaries should not oppose the changes, but work with the new Turkish Government, under a new régime. Barton felt that only by working with the new government could American missionaries protect property and investments in Turkey. ${ }^{100}$

The business community favored the treaty, and asserted that without it American enterprises in Turkey were at a disadvantage against Europeans, paying higher tariffs while Turkish consumers looked to Europe for machinery and manufactured goods. In December, 1925 the Chamber of Commerce of the State of New York adopted a resolution in favor of the treaty. ${ }^{101}$ With its resolution, the New York Chamber of Commerce joined the Chamber of Commerce of the United States in support. In January, 1926 the Board of Directors of the American Manufacturers Export Association adopted a resolution in support of ratification, which was followed by the Association of Cotton Textile Merchants of New York. ${ }^{102}$ In November, 1926 the Chamber of Commerce of the United States reiterated that: "In this country there is a real business interest in Turkey as a present and promising export market for American products." There was also

"further interest in many of the materials of industry available in Turkey. The lack of treaty relations between the United States government and Turkey is a handicap to American trade with Turkey and the Near East... Businessmen are slow to invest capital and build up trading organizations in countries where their rights are not assured by definite and favorable treaty provisions." 103

${ }^{99}$ For example, in 1925 the Council of Turkish-American Relations was formed under the leadership of Asa K. Jennings and Rayford Alley "to promote better understanding between the people of Turkey and the people of the United States." William Borah Papers, Washington, Library of Congress, Box 252.

${ }^{100}$ Robert Daniel, "The United States and the Turkish Republic Before World War II: The Cultural Dimension," Middle East Journal, XXI (1967), 5455. For details on Barton's activities in the Ottoman Empire, see James Barton, Story of Near East Relief, 1915-1930: An Interpretation, New York, 1930.

${ }^{101}$ Borah Papers, Box 252.

${ }^{102}$ Letter from Judson to Borah, William Borah Papers, Box 252.

${ }^{103}$ Resolution by the Chamber of Commerce of the United States, November 5 , 1926, Morgenthau Papers, Reel 33. 
In early 1926, 106 Americans living and working in Turkey sent a petition to the Secretary of State, Frank Kellogg. It said:

"This treaty is not only a satisfactory one, but its terms are in some respects more favorable than those included in the treaties already concluded between Turkey and several of the European powers. If the Lausanne Treaty is not ratified by the United States, the Americans resident in Turkey firmly believe that equally favorable terms could not be secured by subsequent negotiation of another treaty...Failure by the United States to ratify this treaty will result in injury to American interests in Turkey."104

The declaration included the signatures of the President, Vice President and teachers of Robert College, and the President, Dean and teachers of the Istanbul College for Girls, who were joined by representatives of the American Board of Missions, the Young Women's Christian Association and the Young Men's Christian Association, and representatives of the Near East Relief Organization and private philanthropic interests. Businessmen also signed the petition, including the Secretary of the American Chamber of Commerce in Istanbul, the General Manager of the Standard Oil Company in Turkey, executive officers of the Gary and Alston Tobacco Companies, and representatives of American Express and General Motors in İstanbul. ${ }^{105}$

In the early Autumn of 1926 a new organization was formed to unify the supporters and specifically to refute the views expressed by the American Committee Opposed to the Lausanne Treaty. The new group, known as the General Committee of American Institutions and Associations in Favor of Ratification of the Treaty with Turkey, ${ }^{106}$ brought together various arguments and a diverse group of business, missionary and educational interests, and was chaired by Rayford Alley:

"About May 1, 1926 it became apparent that the AmericanTurkish Treaty would fail of ratification by a large margin unless the case in its favor was strongly presented to the Senate and the public. The opposition had already presented its objections effectively in four printed books, while the case for ratification had

${ }^{104}$ Petititon from American Residents of Constantinople Urging Ratification of 105 Ibid.

${ }^{106}$ Rayford Alley, a founder of the Council on Turkish-American Relations became Chairman of the new organization that brought together the American Board of Commissioners for Foreign Missions, the Chamber of Commerce of the Near East, the National Council of the Congregational Churches, the Near East College Association, the YMCA and the YWCA. See Memo by Alley, April 25, 1927, USSD 711.672/591. 
only been presented in separate letters, resolutions and reports of committee, submitted from time to time." 107

Thus, the new organization collected statements and reports in a 164page book, The Treaty with Turkey-Why it Should Be Ratified, and distributed 1.000 copies to Senators and the press. ${ }^{108}$ Furthermore, the General Committee in Favor of Ratification sent correspondence to gather support to 148 institutions and organizations, and press notices favoring the treaty were sent to 889 editors of American newspapers. When Congress reconvened in December, 1926, the General Committee established headquarters at the Raleigh Hotel in Washington in order to lobby senators. On December 17th, 2.000 copies of a new 224-page book in support of the treaty were printed and distributed among policy-makers.

When the Senate reconvened in January, 1927 after the Congressional elections the vote on the Turkish-American Treaty was scheduled for January 18th. On the seventeenth, the General Committee issued an additional statement in favor of the treaty, and distributed 300 copies to senators and the press. ${ }^{109}$ Yet, the Senate voted against the treaty, 50 to 34 , six votes short of the two-thirds majority needed for ratification. After nearly four years of rancorous debate, the treaty with Turkey was defeated. Following the vote, Senators reported three main reasons for rejecting the treaty, First, many felt the new treaty was not as good as the 1830 treaty, since it accepted the abolition of the capitulation. Second, they felt that American commercial interests in Turkey were of minor importance, and it would be wrong to accept a flawed treaty for the sake of a few oil and tobacco companies. Finally, senators referred to the opposition of American religious groups, and claimed the treaty had been rejected on moral grounds. ${ }^{110}$

${ }^{107}$ Memo by Alley, April 25, 1927, USSD 711.672/591.

${ }^{108}$ Overall, the articles in the book stressed three main points of supporters. First, American interests would be hurt if the treaty was not ratified, and the current treaty was as good of a treaty as could be negotiated. Second, rejection of the treaty would do nothing to help Christians in Turkey. Only by ratification could America hope to increase its influence in the Turkish Republic regarding matters of internal affairs. The third issue raised was the reform of institutions and laws which were being carried out by the Turkish Government. According to supporters of the treaty, the Turkish Republic was a modern, democratic and progressive country. Americans would be wise to support the changes occurring in Turkey and the best way to support reforms was by normalizing diplomatic and commercial relations. General Committee of American Institutions and Associations in Favor of Ratification of the Treaty with Turkey, The Treaty with Turkey, New York, 1926.

${ }^{109}$ Memo by Alley, USSD 711.672/591.

${ }^{110}$ State Department Memo, February 8, 1927, USSD 711.672/578. 
7. Aftermath of the Rejection of the Treaty-Restoration of Relations with Turkey and its Implications:

On the day after the Senate rejection, Secretary of State Kellogg instructed Admiral Bristol to give the news of the rejection to the Turkish Government: "You will explain that the executive branch...has spared no efforts to obtain the approval of the treaty by the Senate, and that the explanation of the negative action of the Senate is to be found in the domestic political situation in the United States." 111 Kellogg hoped that the rejection of the treaty would not lead to a strong reaction by the Turkish Government, and instructed Bristol to argue emphatically that the United States "would sincerely regret any change in the friendly relations which have existed during the past few years between the two countries despite the lack of a modern treaty relationship."112

In fact, the Turkish reaction was muted, and comment in the Turkish press emphasized the Turkish Government's view that despite the rejection of the treaty, relations with the United States would continue to develop.

This view was shared by President Calvin Coolidge. When the Senate rejected the treaty, Coolidge was confronted with four options. He could abandon the treaty and relations with Turkey; he could try to negotiate a new treaty, acceptable to the Senate; he could submit it to the Senate for reconsideration, or he could ignore the rejection and use executive powers to establish relations with Turkey. But, the State Department believed it was too late to try to negotiate a new treaty with different terms. Coolidge also concluded that there was little chance the Senate would reconsider the existing treaty without substantial revisions. Therefore, he decided on the fourth option of normalizing relations with Turkey without a formal treaty.

While in Ankara, Admiral Bristol explored possible ways to establish normal diplomatic and commercial relations between Turkey and the United States. Over the course of the next month, the two governments agreed that relations could be confirmed by an exchange of notes, which would grant each other most favored nation status, and allow normal diplomatic and consular functions. On February 17, 1927 a Modus Vivendi agreement was enacted by an exchange of notes. Diplomatic relations were commenced on a temporary basis until June, 1928, with the understanding that arrangements would be made to negotiate a new treaty. ${ }^{113}$

${ }^{111}$ FRUS, 1927, vol. III, p. 766.

112 Ibid.

113 See FRUS, 1927, vol. II, pp. 766-804, for negotiations leading to the exchange of notes. 
The executive initiation of relations with Turkey met with a storm of protest from opponents, and approval from supporters. In April, the Armenian Press Bureau held a mass protest meeting in New York, presided over by Vahan Cardashian, and speakers included Senator William King, James Gerard and David Hunter Miller, the Chairman of the Committee Opposed to the Lausanne Treaty. Cardashian maintained that the treaty had been negotiated "for the promotion of special interests," and argued that while a handful of Americans favored relations with Turkey, nearly a million former subjects of the Ottoman Empire, now American citizens, many of whom had fought in World War I, opposed President Coolidge's decision. ${ }^{114}$ Cardashian also wrote a scathing letter to Secretary of State Kellogg, calling him, Bristol and James Barton "lie factories," and accusing the State Department of entering "a conspiracy with Turkey to steal the homes of a million Armenian refugees and exiles, in the interest of an oil syndicate."115 In May and June, 1927 Armenian-American groups held meetings in New York, Detroit, Cleveland, Chicago, Niagara Falls, Lawrence-Massachusetts, and Racine-Wisconsin, to protest and denounce "the injustices and nefarious designs of the State Department upon the Armenian people and their homes as a reproach to Christianity and to American ideals of justice and fairdealing, and as one of the blackest pages of diplomatic history."116

At the same time, supporters of the treaty were actively pursuing further initiatives. Rayford Alley, of the General Committee in Favor of Ratification of the Treaty with Turkey, wrote to Coolidge in February 1927, urging him to resubmit the treaty to the Senate as soon as possible. Alley was convinced that with additional hearings, the Senate could be persuaded to pass the treaty in the next legislative session. ${ }^{117}$ The General Committee also published a new pamphlet, American Public Opinion Condemns the Failure to Ratify the American-Turkish Treaty, bringing together editorials from newspapers. The pamphlet named seventy-five newspapers that condemned the failure to ratify, and seventeen that supported rejection of the treaty. The Houston Chronicle wrote: "It is hard to see how anything is to be gained by refusing the ratification, and it is easy to see how much may be lost." The New York Evening World wrote: "The rejection of the Lausanne Treaty with Turkey was based on sentiment rather than the realities." The Kansas City Star called the Senate's vote "a futile gesture of protest. It will accomplish nothing except to injure the work and

${ }^{114}$ State Department Memo, April 22, 1927, USSD 711.672/Protests/9.

115 Letter from Cardashian to Kellogg, April 8, 1927, USSD 711.672/ Protests/4.

116"A Resolution," USSD 711.672/Protests/15.

${ }^{117}$ Letter from Alley to Coolidge, USSD 711.672/574. 
standing of Americans in Turkey. The Senate vote is the perfect expression of impractical and ill-informed idealism." 118

Again, for both opponents and supporters, the focus was on the "morality" of the treaty, and the "idealism" that they believed in as the basis of American foreign policy. But there was no clear definition of either the "morality" or the "ideal" that America was expected to represent and foster. While morality was an issue both side addressed, supporters of the treaty shrank away from opponents' critique of the impact of economic considerations on American foreign policy. Indeed, proponents of the treaty were backed by big business interests in the United States, which saw Turkey more as a market than as an ally, and as a source for raw materials, rather than as a new democracy in the Middle East.

In May 1927 President Coolidge took the next step towards establishing normal diplomatic relations with Turkey, by appointing Joseph Grew as ambassador. Grew had been a consistent supporter of better relations with Turkey, and his appointment brought the promise that the new ambassador would work to sway American public opinion away from the image of the "Terrible Turk." Grew arrived at his post in September 1927, and began negotiations for a new treaty between the United States and Turkey. ${ }^{119}$ In September, 1929 a new treaty, based on the original agreement negotiated at Lausanne, was signed by the Turkish and American governments. This time the Senate ratified the treaty after a brief debate, in April, 1930. Grew found it ironic that although "this treaty was not one half as favorable to American interests as the first one, it passed the Senate...without even a tallied vote. Such are politics! But I was satisfied." 120

By April, 1930, nearly seven years had elapsed between the signing of the Treaty of Amity and Commerce by the United States and Turkish Goverments at Lausanne, and the ratification by the American Senate of a new treaty based on the original Lausanne Treaty establishing permanent normal diplomatic relations.

For Turkey, the seven year debate was a telling sign of the future of relations with the United States. as İsmet Inönü later reflected, "at Lausanne,

118 General Committee of American Institutions and Associations in Favor of Ratification of the Treaty with Turkey, "American Public Opinion Condemns the Failure to Ratify the American-Turkish Treaty," included in USSD $711.672 / 568$

${ }^{119}$ For details of Joseph Grew's period as American Ambassador in Ankara, see Grew, Turbulent Era, Vol. II, pp. 709-919.

${ }^{120}$ Grew, "Peace Conference of Lausanne," p. 2. 
Turkey was able to negotiate her own peace treaty,"121 symbolizing Turkey's assertion of itself. Even though the treaty contained problems that influenced Turkish domestic and foreign policy in the future, as Inönü stated, the Lausanne Treaty became a certificate of rebirth of the Turkish Republic on a global level. ${ }^{122}$ In Turkey, the merits of the Lausanne Treaty and the Treaty of Amity and Commerce between Turkey and the United States were also debated among the public and in the Turkish Grand National Assembly. but Turkish foreign policy-makers viewed the American debate and delay in its ratification with concern and curiosity. The seven year delay in ratification of a treaty by the United States Senate was seen neither as a friendly gesture nor as affirmation of American support for the new democratic Turkish Republic.

In America, the debate surrounding the Treaty of Amity and Commerce between the United States and Turkey was not an isolated incident, or a single event. It reflected a long standing expression of ambivalence towards the Ottoman Empire in the public mind, and among policy-makers in the United States. Its timing framed a confrontation which led Americans to rethink existing relations in the post-war world, and it was part of a debate on the changing status of the United States in global affairs. Thus, the seven year long debate was not only about Turkey, but about America's future. Many arguments of this debate continued to surface throughout the period during and after World War II, when America expanded its commitments in the Middle East. In the case of Turkey, two images contended in the minds of policy-makers: the land of the "Terrible Turk" versus the strategic ally and the "open door" in the Middle East. As a result, old feelings of mistrust and the new need to establish trust linked various strands in American foreign policy making, transforming Turkey's image into one of an elusive ally.

${ }^{121}$ Ismet Inönü, "Negotiation and National Interest," in Carnegie Endowment for International Peace, Perspectives on Peace, 1910-1960, London, 1960 , p. 137.

${ }^{122}$ For Ismet Inönü's evaluation of the Lausanne Treaty and its impact, see Inönü, Hatıralar, Vol. II, pp. 153-160. 